\title{
Phylogenetic position of Geitleribactron purpureum (Synechococcales, Cyanobacteria / Cyanophyceae) and its implications for the taxonomy of Chamaesiphonaceae and Leptolyngbyaceae
}

\author{
Jan MAREš $\check{S}^{1,2,3 *} \&$ Marco CANTONATI ${ }^{4}$
}

\author{
${ }^{1}$ Biology Centre of the CAS, v.v.i., Institute of Hydrobiology, Na Sádkách 7, CZ-37005 České Budějovice, Czech \\ Republic \\ ${ }^{2}$ Institute of Botany of the CAS, v.v.i., Centre for Phycology, Dukelská 135, CZ-37982 Třeboň, Czech Republic \\ ${ }^{3}$ Faculty of Science, University of South Bohemia, Department of Botany, Branišovská 1760, CZ-37005 České \\ Budějovice, Czech Republic; *Corresponding authore-mail: jan.mares@centrum.cz \\ ${ }^{4}$ Museo delle Scienze - MUSE, Limnology and Phycology Section, Corso del Lavoro e della Scienza 3, I-38123 \\ Trento, Italy
}

\begin{abstract}
Over the last decades, the taxonomy of cyanobacteria has been considerably improved and restructured due to the increase in data output from molecular phylogeny. Recently, a new protocol was developed that enables reliable sequencing of 16S rRNA genes in cultivation-resistant cyanobacteria using analysis of single cells, filaments, or colonies. In the current study, we examined a sample of a heteropolar unicellular cyanobacterium, Geitleribactron purpureum, from the holotype material (deep epilithon of Lake Tovel, Western Dolomites, Italy). We isolated and purified single colonies of G. purpureum, and subjected them to direct PCR and 16S rRNA gene sequencing. We obtained a congruent set of sequences that formed a unique, isolated cyanobacterial lineage, showing phylogenetic clustering among simple filamentous genera of the family Leptolyngbyaceae. We provide evidence for deep polyphyly in Chamaesiphonaceae, and suggest that Geitleribactron should be re-classified in the Leptolyngbyaceae.
\end{abstract}

Key words: Alps, carbonate lakes, Geitleribactron, heteropolar cyanobacteria, single-colony sequencing, unicellular cyanobacteria

\section{INTRODUCTION}

The taxonomy of cyanobacteria is passing through a difficult period of revision and restructuring with effects on all traditional taxa, as recently summarized by KomÁreK et al. (2014). One of the most challenging tasks of these revisions is the re-definition and splitting of polyphyletic morphogenera and families. The dominant practice in current cyanobacterial taxonomic work is based on the polyphasic approach and the monophyletic species concept (JoHAnsen \& CASAMATTA 2005; Osorio-SANTOS et al. 2014; DvořÁK et al. 2015), which utilizes solely monophyletic taxa recognized on the basis of unique apomorphies (morphological and ultrastructural characters or biochemical and ecophysiological traits). Application of this taxonomic concept has already led to numerous descriptions of new genera and species (KOMÁreK et al. 2014). Recently, PALINSKa \& SuRosz (2014) recommended molecular analysis of botanical type material from historical (and recent) herbaria to generate reference molecular data for existing cyanobacterial species and genera. Such a database might effectively reduce taxonomic confusion caused by phenotypic plasticity of cyanobacterial strains in culture versus natural habitats. Another group of researchers advocated caution and recommended keeping cyanobacterial strains designated with provisional generic names and strain numbers, without species epithets, until better understanding of cyanobacterial species diversity and evolutionary relationships is reached (CAstenholz 1992; Castenholz \& Norris 2005). This approach was used in the current Bergey's Manual of Systematic Bacteriology (CASTEnHolz 2001), which divided the phylum of cyanobacteria into five subsecti- 
ons, each containing several form-genera. Temporary utilization of the standing botanical system was recommended in floristic and ecological studies lacking culture isolates (CASTENHOLZ 1992).

Among the groups whose modern revision has not yet been fully accomplished, one of the least understood are heteropolar unicellular cyanobacteria. According to KoMÁREK et al. (2014), polarized cyanobacterial unicells are classified into three standalone families, each putatively placed in a different order: Chamaesiphonaceae (Synechococcales), part of the Dermocarpellaceae (Pleurocapsales), and Stichosiphonaceae (Chroococcales). The present study is concerned mainly with members of the Chamaesiphonaceae. Cyanobacteria from this family are supposed to be relatively simple, solitary, or colonial, exhibiting asymmetrical binary fission, producing one or few exocytes, and having parietally arranged thylakoids (KOMÁREK \& Anagnostidis 1998; KomÁrek et al. 2014). By contrast, Dermocarpellaceae and Stichosiphonaceae show irregular thylakoid patterns and extensive production of special reproductive cells, namely, baeocytes and exocytes, respectively. Nevertheless, the boundaries between these groups or genera within a single group are sometimes considered to be problematic. For example, Rosowski et al. (1995) observed a cyanobacterial strain resembling Geitleribactron, which formed long $\mathrm{Y}$-shaped cells typical of Cyanophanon (both Chamaesiphonaceae). A recently described morphospecies Chamaesiphon stratosus SANT'ANNA et al. from Brazil (SANT'ANNA et al. 2011) showed a colony organization exhibiting features of both Chamaesiphonopsis (Chamaesiphonaceae) and Godlewskia (Stichosiphonaceae). Another study by GolD-MorgAn et al. (2015) described a new coccoid heteropolar genus $\mathrm{Ni}$ sida exhibiting a morphology that did not allow classification of the taxon in any of the existing families. The authors of all of the three above-mentioned studies were unable to sequence their material, and the authors of the latter two studies did not provide information on thylakoid arrangement. Without these essential pieces of evidence, no reliable taxonomic conclusions can be reached.

The Chamaesiphonaceae currently comprise five genera: Chamaesiphon, Chamaesiphonopsis, Clastidium, Cyanophanon, and Geitleribactron (KoMÁREK et al. 2014). Although these cyanobacteria are not very often studied in detail, they are capable of establishing ecologically significant populations in certain biotopes. Species of Chamaesiphon, the most frequent of these genera, commonly colonize water vegetation and hard substrates in both running and stagnant, usually clear and cool, waters (KOMÁREK \& ANAGNOSTIDIS 1998). Outside Europe, interesting reports of the genus come from, e.g., the Atlantic rainforest in Brazil (SANT'AnNA et al. 2011), Himalaya (KomÁreK \& WatANABE 1998), Mexico (Gold-Morgan et al. 1996), Australia (McGregor 2013), and even Antarctica (KomÁrek
2014). The abundance and relatively narrow ecological valence of Chamaesiphon species in stream biofilms have enabled their use in water quality assessment and bioindication (BARINOvA et al. 2008; RotT 2008; NIEDERMAYr \& Schagerl 2010; Loza et al. 2013a, b).

Another genus with some practical importance is Geitleribactron, although it is only rarely reported in the literature (Golubić 1967; Geitler 1970, 1975; KomÁreK 1975; Hällfors \& Munsterhjelm 1982; Gold-Morgan et al. 1996; Karosienė \& KasperoviČIENĖ 2008; Biolo \& Rodrigues 2011; CANTONATI et al. 2014a). The four known Geitleribactron species are characterized by a very simple morphology: rod-shaped unicells lacking a sheath are attached to the substrate with an inconspicuous mucilaginous pad, cells divide somewhat asymmetrically, producing a single exocyte, and the thylakoids are arranged parietally (Komárek \& Anagnostidis 1998; Cantonati et al. 2014a). The type species, G. periphyticum KomÁreK, is sometimes considered an expansive species in Europe, where it is potentially problematic for water-treatment facilities because its small size interferes with water filters (KAŠTOvsKÝ et al. 2010). Recently, a new species, G. purpureum CANTONATI et KomÁReK, which is distinguishable from the generitype mostly by its bright purple color and habitat, was described from the epilithon of Lake Tovel, Italy (CANTONATI et al. 2014a). This meromictic/oligomictic, carbonate mountain lake of the south-eastern Alps hosts a set of distinguishable phytobenthic communities along its depth/irradiance gradient (CAntonati et al. 2014b). Purple cyanobacterial species (G. purpureum, Chlorogloea purpurea GEITLER) seem to have adapted to the low light availability at greater depths.

The major shortcoming in our knowledge of heteropolar unicellular cyanobacteria is the overall lack of molecular data. The only genus with a relatively good DNA sequence record is Chamaesiphon (TURNER 1997; LozA et al. 2013b; SHin et al. 2013), although its type species (C. confervicola A. BRAUn in RABENHORST) has not yet been analyzed using molecular methods. DNA sequence data on other genera are not available. Authors of recent studies agree on the resistance of these cyanobacteria to isolation into culture (SANT'ANNA et al. 2011; CAntonati et al. 2014a; Gold-MorGAN et al. 2015), probably because they have specific growth requirements. Until these problems are solved, cultivation-independent molecular approaches provide the only viable alternative to studying these species. One of these techniques, recently introduced by us for terrestrial cyanobacteria (MAREŠ et al. 2015), holds promise for the direct sequencing of the $16 \mathrm{~S}$ rRNA gene in single cells or colonies present in morphologically distinct, uncultured cyanobacterial specimens. In the current study, we examined a sample (colonies on cobble collected by SCUBA divers in Lake Tovel, Italy) of the type material of Geitleribactron purpureum, using the single-colony sequencing approach. 
Details concerning the ecology of the studied G. purpureum population and the associated microalgal assemblages were provided in previous studies (CANTONATI et al. 2009; CANTONATI et al. 2014a, b). The results of molecular analysis are discussed within the taxonomic framework of the Chamaesiphonaceae and other relevant cyanobacterial groups.

\section{Material and Methods}

Study site, sampling procedures, and morphological observations. Lake Tovel (south-eastern Alps, Adamello-Brenta Nature Park) is a carbonate (geological substratum: dolomite and limestone), meromictic (with a tendency to oligomixis), mountain lake (1178 $\mathrm{m}$ a.s.1.) affected by marked seasonal water-level fluctuations that never exceed $9 \mathrm{~m}$ (CAntonati et al. 2014c). Maximum depth is $39 \mathrm{~m}$, average Secchi disk depth is about $10 \mathrm{~m}$, and average lower limit of the euphotic zone is approximately $24 \mathrm{~m}$ (CANTONATI et al. 2014b).

The cobble used in this study (Fig. 1a) was part of the holotype material of Geitleribactron purpureum (cobbles collected by SCUBA divers in June 2013 in the depth-distribution range of the species, 9-21 m). The holotype is stored in the collections of the Museo delle Scienze - MUSE of
Trento, Italy (Code: cLIM009 PHYTOB 796) (CANTONATI et al. 2014a).

An epilithic assemblage dominated by G. purpureum was scraped from the stone surface and observed using a Zeiss Axioskop 2 (Zeiss, Jena, Germany) light microscope at $1000 \times$ magnification equipped with a Zeiss Axiocam digital camera to document the morphology of the cells and colonies.

Molecular analysis. For molecular analysis, single small sub-colonies of $G$. purpureum containing approximately 5 20 cells were isolated from the same holotype stone used for the morphological analysis. The protocol followed exactly the procedures described by MAREŠ et al. (2015). Briefly, fresh material containing G. purpureum was scraped from the stone surface and homogenized with a needle in TE buffer. Using a microscope, six individual colonies were picked with a glass capillary, washed several times in TE buffer, and checked for contaminants. Clean colonies were placed individually into separate PCR tubes, and a partial $16 \mathrm{~S}$ rRNA gene sequence was amplified in two steps using a semi-nested PCR protocol with cyanobacteria-specific primers (see MAREŠ et al. 2015 for details). Samples containing the PCR product of the predicted length (about $1100 \mathrm{bp}$ ) were cloned into $E$. coli using the pGEM ${ }^{\circledR}-\mathrm{T}$ Easy vector system (Promega, Madison, WI, USA), and the resulting plasmids were purified using NucleoSpin ${ }^{\circledR}$ Plasmid kit (Macherey-Nagel, Düren, Germany), and sequenced in SeqMe, s.r.o. (Dobřríš,
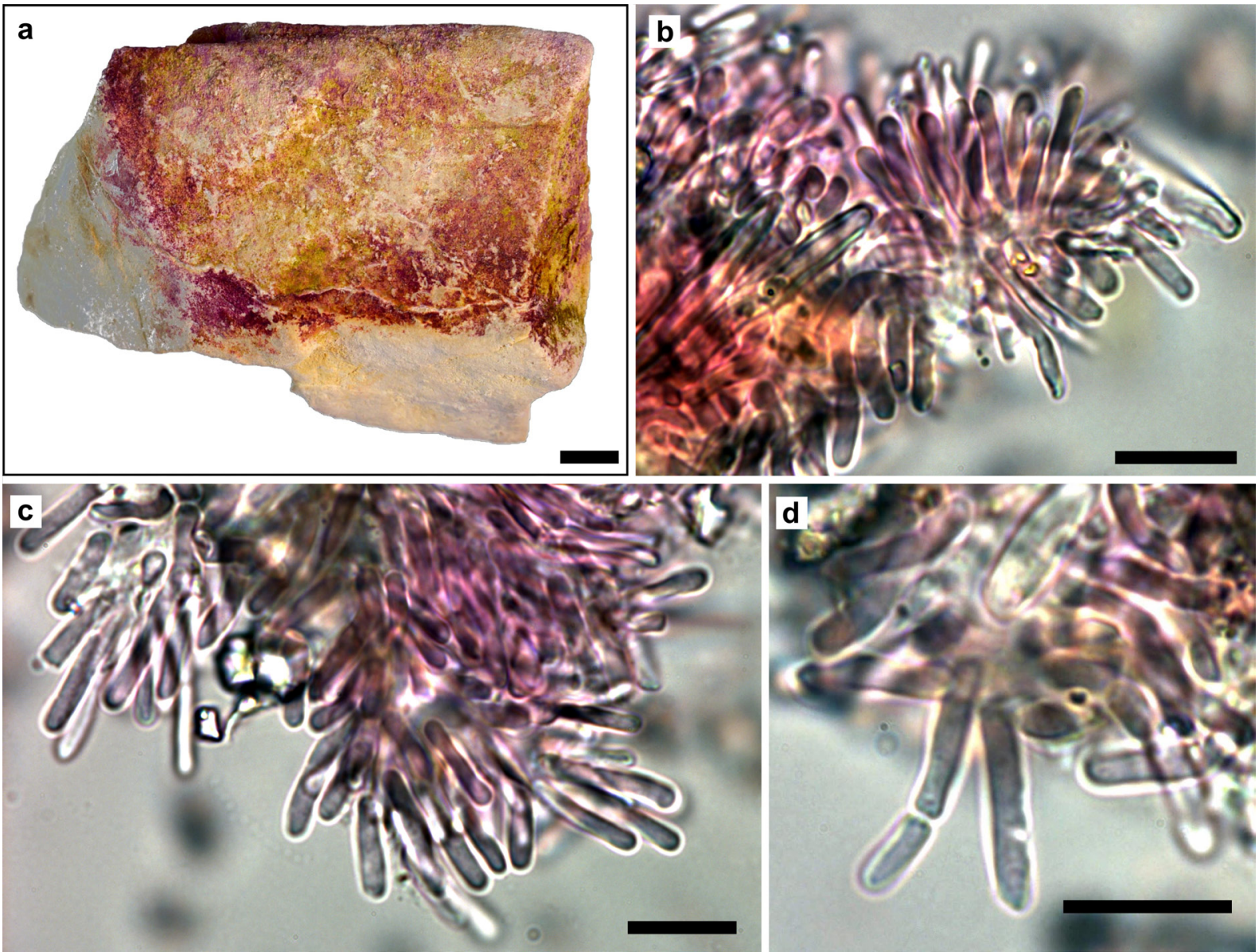

Fig 1. Morphology of Geitleribactron purpureum from the holotype material: (a) a cobble covered by a purple biofilm, dominated by G. purpureum; (b-c) typical stellate colonies of G. purpureum; (d) detail of asymmetrical binary fission. Scale bars: (a) $1 \mathrm{~cm}$; (b-d) $10 \mu \mathrm{m}$. 


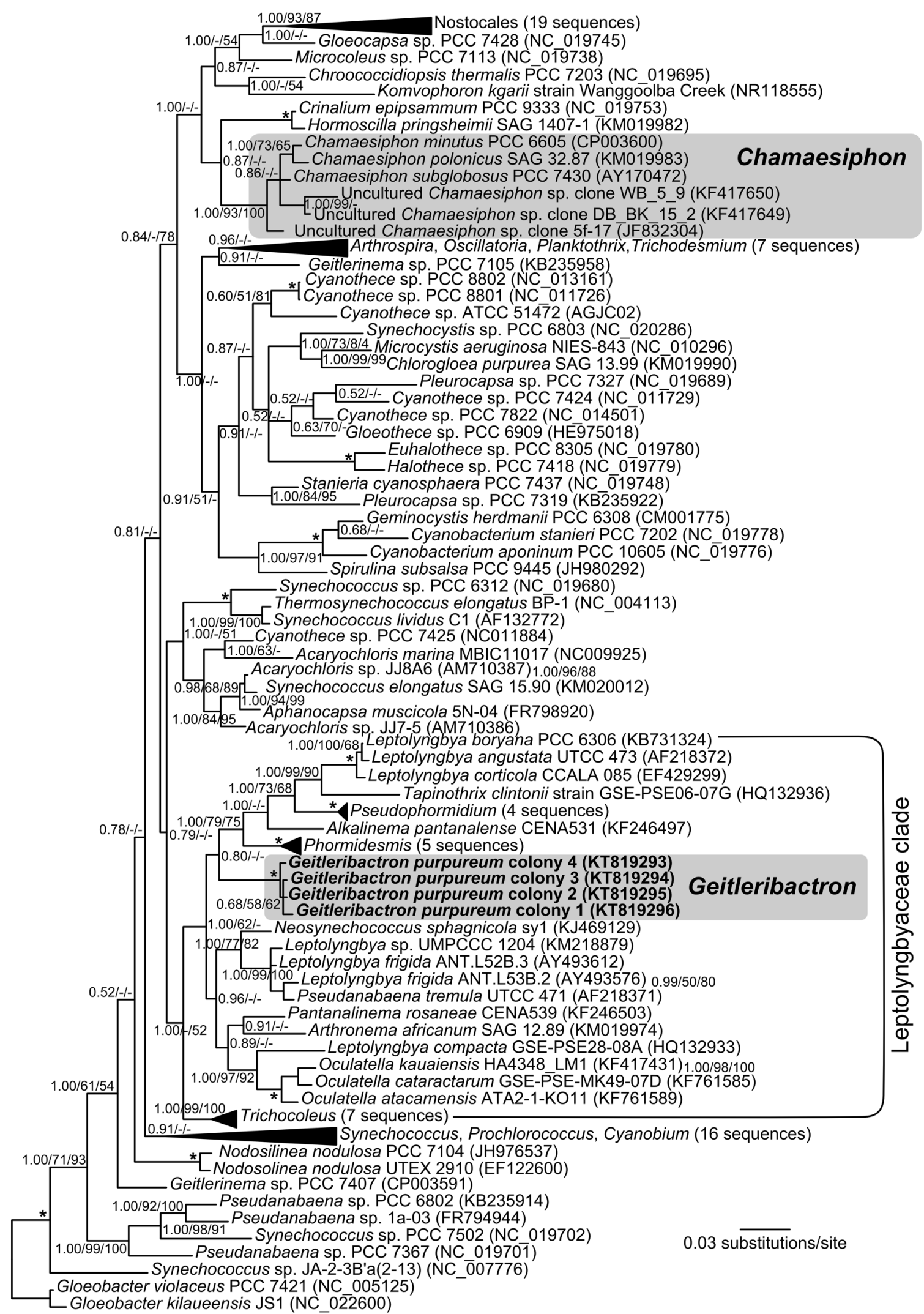

Fig 2. Phylogenetic tree (Bayesian Inference) of cyanobacteria inferred from a partial 16S rRNA gene alignment, showing the position of Geitleribactron purpureum in the Leptolyngbyaceae, and the distant position of Chamaesiphon species. Branch support values $>50 \%$ are given near nodes in this shape: Bayesian Inference/Maximum Likelihood/Neighbor-Joining. Full support from all methods is marked with asterisks. Sequences obtained in this study are printed in bold. 
Czech Republic) using standard plasmid primers (T7promoter and SP6r).

The DNA sequences were aligned using the G-INS- $\mathrm{i}$ algorithm using the default parameters of MAFFT v. 7 (KATOH \& STANDLEY 2013) with a set of published Chamaesiphon sequences, and the sequences of members of other clusters of coccoid cyanobacteria, close BLAST hits, and a few representatives of all major cyanobacteria clades. The alignment produced by MAFFT was manually checked, and converted into a 1087 nucleotide long matrix of 128 sequences covering the major part of the 16S rRNA gene. Phylogeny was reconstructed using Bayesian Inference (BI), Maximum Likelihood (ML), and Neighbor-Joining (NJ) methods using the Gloeobacter violaceus strains as an outgroup for other members of the cyanobacteria. The BI calculation was executed in MrBayes 3.2.3 via MetaCentrum supercomputing grid (www.metacentrum.cz); two runs of eight Markov chains were performed for 1275000 generations, and sampled each 100 generations until the convergence criterion reached a value $<0.01$. The first $25 \%$ of the sampled data was discarded as burn-in. The ML analysis in RaxML v. 8 (STAMATAKis 2014) was run on a CIPRES supercomputing facility (MILLER et al. 2012) employing the general time-reversible + invariant + gamma $(\mathrm{GTR}+\mathrm{I}+\mathrm{G})$ substitution model, with 1000 bootstrap pseudo-replications. The NJ analysis was run in SeaView v. 4 (Gouy et al. 2010) using the BioNJ algorithm (GASCUEL 1997) and Jukes-Cantor substitution model, with 1000 bootstrap pseudo-replications. Nucleotide sequence identities were calculated as pairwise $\mathrm{p}$-distances using the Sequence Identity Matrix tool in BioEdit v. 7 (HaLl 1999).

\section{Results}

\section{Morphology}

The studied holotype material contained a microbial assemblage in the form of a purple-colored biofilm that was tightly attached to the parts of the stone exposed to light (Fig. 1a). The biofilm was dominated by $G$. purpureum, with minor contributions from other cyanobacteria and diatoms. Morphology and ultrastructure were thoroughly investigated and described in our previous study (CANTONATI et al. 2014a). For the purpose of subsequent molecular analysis, we re-examined the morphology of $G$. purpureum in the sample used for the isolation and sequencing of single colonies. Several typical colonies of $G$. purpureum from the sample investigated in this study are shown in Fig. $1 \mathrm{~b}-\mathrm{d}$. These colonies were further homogenized, and small sub-colonies consisting of 5-20 cells free of contaminants were used for molecular analysis.

\section{Molecular analysis}

Six pure sub-colonies were successfully extracted from the biofilm and subjected to PCR amplification. Four of them provided a PCR product of the partial 16S rRNA gene, which was subsequently sequenced. The resulting sequences of G. purpureum were 1095 bp long and highly uniform (sequence identity 99.0 99.6\%). The sequences were deposited in GenBank (http://www.ncbi.nlm.nih.gov/genbank/) under accession numbers KT819293-296.

The phylogenetic tree resulting from BI analysis (with branch support values from other methods mapped on its nodes) is shown in Fig. 2. In this tree, $G$. purpureum formed a tight cluster $(100 \%$ branch support) with strains of cyanobacterial genera such as Leptolyngbya, Tapinothrix, Pseudophormidium, Phormidesmis, Oculatella, Pantanalinema, Alkalinema, and Arthronema, and several sequences of unclear taxonomy, putatively placed in Leptolyngbya and Pseudanabaena. This clustering was supported using all methods (branch support BI/ML/NJ = 1.00/77/82). This group of strains, typified by Leptolyngbya boryana (GomONT) ANAGNOSTIDIS et KOMÁREK (strain PCC 6306), together with a sister branch of Trichocoleus, represents the family Leptolyngbyaceae. It includes mostly simple and thin $(\leq 3 \mu \mathrm{m}$ wide) filamentous cyanobacteria, with the exception of Neosynechococcus sphagnicola DvořÁK et al. (strain sy1), which is a rod-shaped coccoid cyanobacterium. Although $G$. purpureum 16S rRNA gene sequences were highly unique, and only 92.5-93.0\% identical along the aligned region to the most similar sequences of leptolyngbyacean taxa (Phormidesmis, Trichocoleus), they were even less similar to the bestmatching sequence of Chamaesiphon $(91.0 \%)$.

In our phylogeny, the rest of the currently accepted family Chamaesiphonaceae was represented by the only available sequenced genus, Chamaesiphon, which formed a well-supported cluster (branch supports $>90 \%$ ), recovered in a phylogenetic clade distant from Leptolyngbyaceae. Based on the BI topology, this cluster may be affiliated to Gomontiellaceae and other derived groups, and have a closer relationship with chroococcalean and nostocalean cyanobacteria than with synechococcalean types, including G. purpureum. Thus, our data provide strong evidence for a deep polyphyly in Chamaesiphonales.

\section{Discussion}

Heteropolar unicellular cyanobacteria are one of the least understood groups of blue-green algae (GoLDMorgan et al. 2015) despite recent phylum-wide revisionary efforts (KOMÁREK et al. 2014). In the current study, we provide for the first time DNA sequence data for Geitleribactron, representing the second sequence record for Chamaesiphonaceae genera (in addition to several available Chamaesiphon sequences). Molecular data support the taxonomic position of Geitleribactron as a separate genus (KOMÁREK 1975), because it formed an isolated phylogenetic lineage and showed only approximately $93 \% 16 \mathrm{~S}$ rRNA sequence identity to those of its closest strains. Nevertheless, this conclusion is only preliminary and should be further verified by molecular analysis of the generitype, G. periphy- 
ticum, in a future study. Ideally, such analysis should involve herbarium type material or material from the type locality of $G$. periphyticum, as recommended by PALINSKA \& Surosz (2014). Because our study was based on a single population, additional molecular data from different localities are required to provide more insight into the variability within the genus. Given the evidence on morphological convergence and extreme polyphyly in other simple unicellular cyanobacteria (DVoŘÁk et al. 2014a), monophyly of Geitleribactron needs to be verified by sequencing more of its species.

According to the phylogenetic reconstruction (Fig. 2), G. purpureum clearly clustered within a group of simple filamentous cyanobacterial genera, which are considered here as Leptolyngbyaceae. This clade, typified by L. boryana (type of the family), has been reported previously as a well-established lineage (CASAmatta et al. 2005; Bohunické et al. 2011; Perkerson et al. 2011). The name Leptolyngbyaceae is in accordance with the standing cyanobacterial system (KomÁREK et al. 2014). Thus, it should be preferred to older names such as Pseudanabaenaceae (Perkerson et al. 2011; VAz et al. 2015), which is now reserved for a group of several genera not including Leptolyngbya and related taxa. Recently, the group has been subject to intensive taxonomic research that has already yielded several new genera, such as Phormidesmis (KoMÁREK et al. 2009), Oculatella (ZAMMIT et al. 2012), Alakalinema, and Pantanalinema (VAZ et al. 2015). Clustering of a coccoid cyanobacterium inside a predominantly filamentous group is generally not surprising, since repeated emergence and loss of multicellularity in the course of cyanobacterial evolution has already been documented (SCHIRRMEISTER et al. 2011, 2013; Dvoř́́K et al. 2014a). Nevertheless, only a single well-described example has been reported in Leptolyngbyaceae: the recently established genus $\mathrm{Ne}$ osynechococcus (Dvoř́́k et al. 2014b). Interestingly, this peculiar coccoid cyanobacterium is capable of forming extremely elongated cells (up to $20 \mu \mathrm{m}$ in situ and up to $70 \mu \mathrm{m}$ in culture), which is a feature that resembles the long cylindrical cells of $G$. purpureum (around 10-20 $\mu \mathrm{m}$ upon division (Fig. $1 \mathrm{~b}-\mathrm{d}$ ). Thus, the filiform shape observed in both genera may be a typical feature of unicellular Leptolyngbyaceae. However, Neosynechococcus and Geitleribactron did not form a monophyletic cluster in our phylogenetic tree, suggesting that the loss of ability to form long multicellular filaments may have occurred several times. Moreover, G. purpureum is characterized by its exclusively heteropolar growth. Simple heteropolar filamentous cyanobacteria are currently classified in a separate family, the Heteroleibleiniaceae, which comprises two genera: Heteroleibleinia and Tapinothrix (KOMÁREK et al. 2014). Together with Tapinothrix clintonii BoHUNICKÁ et JOHANSEN (BoHUNickÁ et al. 2011), G. purpureum is the second example of a heteropolar cyanobacterium closely related to Leptolyngbya sensu stricto. Thus, the available evidence does not favor Heteroleibleiniaceae as a standalone family, and suggests it should be merged with Leptolyngbyaceae. This will again be possible only after careful analysis of a greater number of isolates, including the generitypes.

Our phylogeny, although it was based solely on partial 16S rRNA gene data, seems to unequivocally show a deep polyphyly in Chamaesiphonaceae. The sequenced members of Chamaesiphon clustered in a lineage distant from that of Leptolyngbyaceae. The 16S rRNA gene alone usually does not provide robust phylogenetic signal at higher taxonomic levels. Thus, multilocus or genome-wide comparisons are recommended for establishing reliable relationships among broader groups of cyanobacteria (DvořÁK et al. 2015). Although the higher phylogenetic backbone was not statistically well supported in our current tree (Fig. 2), a similar branching of Chamaesiphon and Leptolyngbya was previously observed in both $16 \mathrm{~S}$ rRNA-based (Loza et al. 2013b) and phylogenomic (SHiн et al. 2013; KOMÁREK et al. 2014) reconstructions. Therefore, we suggest the re-classification of the genus Geitleribactron to place it within the Leptolyngbyaceae. While our conclusion is likely correct, a future study employing molecular phylogenetic analysis of the type species of Geitleribactron and Chamaesiphon using multiple genomic loci will be required to obtain an ultimate validation.

ACKNOWLedGements

The study was supported by the Czech Science Foundation project no. 15-00113S and the long-term research development project no. RVO 67985939. MC was partially funded by the Autonomous Province of Trento while contributing to this study. Computational resources were provided by the MetaCentrum under the program LM2010005 and the CERIT-SC under the program Centre CERIT Scientific Cloud, part of the Operational Program Research and Development for Innovations, Reg. no. CZ.1.05/3.2.00/08.0144. We are grateful to the SCUBA divers of the permanent fire brigade of Trento for collecting the stones used to obtain the colonies studied in this paper.

\section{REFERENCES}

Barinova, S.; Medvedeva, L. \& Nevo, E. (2008): Regional influences on algal biodiversity in two polluted rivers of Eurasia (Rudnaya River, Russia, and Qishon River, Israel) by bioindication and canonical correspondence analysis. - Appl. Ecol. Env. Res. 6: 29-59.

Biolo, S. \& Rodrigues, L. (2011): Composição de algas perifíticas (exceto Bacillariophyceae) em distintos substratos naturais de um ambiente semilótico, planície de inundação do Alto Rio Paraná, Brasil. - Revista Brasil. Bot. 34: 307-319.

BohunickÁ, M.; Johansen, J. R. \& FuČíKovÁ, K. (2011): Tapinothrix clintonii sp. nov. (Pseudanabaenaceae, Cyanobacteria), a new species at the nexus of five genera. - Fottea 11: 127-140.

Cantonati, M.; Guella, G.; Komárek, J. \& Spitale, D. (2014b): Depth distribution of epilithic cyanobacte- 
ria and pigments in a mountain lake characterized by marked water-level fluctuations. - Freshw. Sci. 33: $537-547$

Cantonati, M.; Guella, G.; Settale, D.; Angeli, N.; BorsaTO, A.; Lencioni, V. \& FiliPPI, M.L. (2014c): The contribution of lake benthic algae to the sediment record in a carbonate mountain lake influenced by marked natural water-level fluctuations. - Freshw. Sci. 33: 499-512.

Cantonati, M.; Komárek, J.; Hernández-Mariné, M. \& Angeli, N. (2014a): New and poorly known coccoid species (Cyanoprokaryota) from the mid-depth and deep epilithon of a carbonate mountain lake. Freshw. Sci. 33: 548-556.

Cantonati, M.; Scola, S.; Angeli, N.; Guella, G. \& FrassaNITO, R. (2009): Environmental controls of epilithic diatom depth-distribution in an oligotrophic lake characterised by marked water-level fluctuations. Eur. J. Phycol. 44: 15-29.

Casamatta, D. A.; Johansen, J. R.; Vis, M. L. \& BroadwaTER, S. T. (2005): Molecular and morphological characterization of ten polar and near-polar strains within the Oscillatoriales (Cyanobacteria). - J. Phycol. 41: 421-438.

Castenholz, R. W. (1992): Species usage, concept, and evolution in the Cyanobacteria (blue-green algae). - J. Phycol. 28:737-745.

Castenholz, R. W. (2001): Phylum BX. Cyanobacteria. - In: Boone, D. R. \& CAstenholz, R. W. (eds): Bergey's Manual of Systematic Bacteriology. - pp. 473-599, Springer, New York.

Castenholz, R. W. \& Norris, T. B. (2005): Revisionary concepts of species in the Cyanobacteria and their applications. - Algological Studies 117: 53-69.

Dvořák, P.; Casamatta, D. A.; PoulíčKovÁ, A.; Hašler, P.; OndŘEJ, V. \& SANGES, R. (2014a): Synechococcus: 3 billion years of global dominance. - Mol. Ecol. 23: 5538-5551.

Dvořák, P.; Hindák, F.; Hašler, P.; Hindáková, A. \& PoulíčKovÁ, A. (2014b): Morphological and molecular studies of Neosynechococcus sphagnicola, gen. et sp. nov. (Cyanobacteria, Chroococcales). - Phytotaxa 170: 24-34.

Dvořák, P.; PoulíčKovÁ, A.; Hašler, P.; Belli, M.; CASAmatTA, D. A. \& PAPINI, A. (2015): Species concepts and speciation factors in cyanobacteria, with connection to the problems of diversity and classification. - Biodivers. Conserv. 24: 739-757.

GASCUEL, O. (1997): BIONJ: an improved version of the NJ algorithm based on a simple model of sequence data. - Mol. Biol. Evol. 14: 685-95.

Geitler, L. (1970): Beiträge zur epiphytischen Algenflora des Neusiedler Sees. - Österr. Bot. Ztschr. 118: $17-29$.

Geitler., L. (1975). Zur vergleichenden Morphologie der Cyanophycee Clastidium setigerum und verwandten Gattungen. - Plant Syst. Evol. 124: 161-171.

Gold-Morgan, M.; GonzÁleZ-Resendiz, L.; LeÓn-Tejera, H. \& Montejano, G. (2015): Description of coccoid cyanoprokaryote Nisada stipitata morphogen. et sp. nov. from the supralittoral zone in the tropical Mexican Pacific. - Phytotaxa 220: 268-276.

Golubić, S. (1967): Die littorale Algenvegetation des Titisees. - Arch. Hydrobiol./Suppl. 33: 172-205.

Gouy, M.; Guindon, S. \& Gascuel, O. (2010): SeaView ver- sion 4: a multiplatform graphical user interface for sequence alignment and phylogenetic tree building. - Mol. Biol. Evol. 27: 221-4.

Hall, T. A. 1999. BioEdit: a user-friendly biological sequence alignment editor and analysis program for Windows 95 / 98 / NT. - Nucleic Acids Symp. Ser. 41: $95-8$

Hällfors, G. \& Munsterhjelm, R. (1982): Some epiphytic Chamaesiphonales from fresh and brackish water in southern Finland. - Ann. Bot. Fenn. 19: 147-176.

Johansen, J. R. \& Casamatta, D. A. (2005): Recognizing cyanobacterial diversity through adoption of a new species paradigm. - Algol. Stud. 117: 71-93.

KarosienĖ, J. \& KASPERoviČIENĖ, J. (2008): Epiphyton Chroococcales cyanobacteria species new to algaeflora of Lithuanian freshwaters. - Bot. Lith. 14: 159-169.

Kaštovský, J.; Hauer, T.; Mareš, J.; KrautovÁ, M.; Bešta, T.; KomÁrek, J.; Desortová, B.; Heteša, J.; HindákovÁ, A.; Houk, V.; JANeČEK, E.; Kopp, R.; MARVAn, P.; Pumann, P.; SkÁcelová, O. \& ZapomĚlová., E. (2010): A review of the alien and expansive species of freshwater cyanobacteria and algae in the Czech Republic. - Biol. Invasions 12: 3599-3625.

Katoh, K. \& Standley, D. M. (2013): MAFFT multiple sequence alignment software version 7: improvements in performance and usability. - Mol. Biol. Evol. 30: $772-780$.

KomÁreK, J. (1975): Geitleribactron - eine neue, Chamaesiphon-ähnliche Blaualgengattung. - Plant Syst. Evol. 123: 263-281.

KomÁrek, J. (2014): Phenotypic and ecological diversity of freshwater coccoid cyanobacteria from maritime Antarctica and Islands of NW Weddell Sea. II. Czech Polar Reports 4: 16-39.

KomÁReK, J. \& AnAgnostidis, K. (1998): Cyanoprokaryota I. - In: Ettl, H.; Gärtner, G.; Heynig, H. \& MolLENHAUER, D. (eds): Süßwasserflora von Mitteleuropa, Band 19/1. - 548 pp., Gustav Fischer Verlag, Stuttgart - Jena.

Komárek, J.; KaštovskÝ, J.; Mareš, J. \& Johansen, J. R. (2014): Taxonomic classification of cyanoprokaryotes (cyanobacterial genera) 2014, using a polyphasic approach. - Preslia 86: 295-335.

Komárek, J.; Kaštovský, J.; Ventura, S.; Turicchia, S. \& Šmarda, J. (2009): The cyanobacterial genus Phormidesmis. - Algol. Stud. 129: 41-59.

Loza, V.; Perona, E. \& Mateo, P. (2013a): Molecular fingerprinting of cyanobacteria from river biofilms as a water quality monitoring tool. - Appl. Env. Microbiol. 79: 1459-72.

Loza, V.; Berrendero, E.; Perona, E. \& Mateo, P. (2013b): Polyphasic characterization of benthic cyanobacterial diversity from biofilms of the Guadarrama River (Spain): morphological, molecular, and ecological approaches. - J. Phycol. 49: 282-297.

Mareš, J.; Lara, Y.; Dadáková, I.; Hauer, T.; Uher, B.; Wilmotte, A. \& KaštovskÝ, J. (2015): Phylogenetic analysis of cultivation-resistant terrestrial cyanobacteria with massive sheaths (Stigonema spp. and Petalonema alatum, Nostocales, Cyanobacteria) using single-cell and filament sequencing of environmental samples. - J. Phycol. 51: 288-297.

McGregor, G. B. (2013): Freshwater Cyanobacteria of North-Eastern Australia: 2. Chroococcales. - Phyto- 
taxa 133: $1-130$.

Miller, M. A.; Pfeiffer, W. \& Schwartz, T. (2012): The CIPRES science gateway: enabling high-impact science for phylogenetics researchers with limited resources. - In: Proceedings of the 1st Conference of the Extreme Science and Engineering Discovery Environment: Bridging from the eXtreme to the campus and beyond. - pp. 1-8, ACM, Chicago, Illinois.

Niedermayr, R. \& Schagerl, M. (2010): Structuring factors of the phytobenthos community along a mountain headwater (Kalkalpen National Park, Austria). Fundam. Appl. Limnol. 177: 93-104.

Osorio-Santos, K.; Pietrasiak, N.; BohunickÁ, M.; Miscoe, L. H.; KováČiK, L'; Martin, M. P. \& Johansen, J. R. (2014): Seven new species of Oculatella (Pseudanabaenales, Cyanobacteria). - Eur. J. Phycol. 49: 450-470.

Palinska, K. A. \& Surosz, W. (2014): Taxonomy of cyanobacteria: a contribution to consensus approach. - Hydrobiologia 740: 1-11.

Perkerson, R. B.; Johansen, J. R.; Kováčik, L'.; Brand, J.; KaštovskÝ, J. \& CasamatTa, D. A. (2011): A unique pseudanabaenalean (Cyanobacteria) genus Nodosilinea gen. nov. based on morphological and molecular data. - J. Phycol. 47: 1397-1412.

Rosowski, J. R.; BIELIK, I. \& LeE, K. W. (1995): Observations on a chamaesiphonaceous alga (Cyanophyceae) with special reference to exocyte formation. - J. Phycol. 31: 435-446.

Rotт, E. (2008): Chamaesiphon komárekii species nova, a new benthic freshwater chroococcalean species (Cyanophyta/ Cyanobacteria) from western coniferous forest streams in British Columbia, Canada. - Algol. Stud. 126: 37-46.

SAnt'Anna, C. L.; Gama-JR., W. A.; Azevedo, M. T. P. \& KomÁREK, J. (2011): New morphospecies of Chamaesiphon (Cyanobacteria) from Atlantic rainforest, Brazil. - Fottea 11: 25-30.
Schirrmeister, B. E.; Antonelli, A. \& Bagheri, H. C. (2011): The origin of multicellularity in cyanobacteria. BMC Evol. Biol. 11: 45.

Schirrmeister, B. E.; DeVos, J. M.; Antonelli, A. \& BaghERI, H. C. (2013): Evolution of multicellularity coincided with increased diversification of cyanobacteria and the Great Oxidation Event. - Proc. Natl. Acad. Sci. USA 110: 1791-1796.

Shih, P. M.; Wu, D.; Latifi, A.; Axen, S. D.; Fewer, D. P.; Talla, E.; Calteau, A.; Cai, F.; Tandeau de Marsac, N.; Rippka, R.; Herdman, M.; Sivonen, K.; Coursin, T.; LAURENT, T.; GoOdwin, L.; Nolan, M.; DaVEnPORT, K. W.; Han, C. S.; Rubin, E. M.; EISEN, J. A.; Woyke, T.; Gugger, M. \& Kerfeld, C. A. (2013): Improving the coverage of the cyanobacterial phylum using diversity-driven genome sequencing. - Proc. Natl. Acad. Sci. USA 110:1053-1058.

StAMATAKIS, A. (2014): RAxML version 8: A tool for phylogenetic analysis and post-analysis of large phylogenies. - Bioinformatics 30: 1312-1313.

TURNER, S. (1997): Molecular systematics of oxygenic photosynthetic bacteria. - Plant Syst. Evol. 11: 53-86.

Vaz, M. G. M. V.; Genuário, D. B.; Andreote, A. P. D.; Malone, C. F. S.; Sant'Anna, C. L.; Barbiero, L. $\&$ Fiore, M. F. (2015): Pantanalinema gen. nov. and Alkalinema gen. nov.: Novel pseudanabaenacean genera (Cyanobacteria) isolated from saline-alkaline lakes. - Int. J. Syst. Evol. Microbiol. 65: 298-308.

Zammit, G.; Billi, D. \& Albertano, P. (2012): The subaerophytic cyanobacterium Oculatella subterranea (Oscillatoriales, Cyanophyceae) gen. et sp. nov.: a cytomorphological and molecular description. - Eur. J. Phycol. 47: 341-354.

(C) Czech Phycological Society (2016)

Received September 21, 2015

Accepted January 2, 2016 